\title{
A political history of visual display
}

\author{
The Poster (2017), 4(1/2):7-29.
}

\author{
Anne Krogstad
}

Images are effective tools of political persuasion. While not aiming at a comprehensive overview, this article tries to capture the visual mode of political communication by studying how the portrayal of politicians provides the public with knowledge about the world of politics during different information eras. The main question is how the development of new forms of media, each with individual possibilities and restrictions regarding display, access, reach and storage, facilitate specific forms of visual politics. Visual presentations of politicians are analyzed in their face-to-face interaction with a public, as well as in sculptures, paintings, photographs, film, television and digital media. Central questions are what images are displayed, how are they displayed and with what media technology. Also examined are rhetorical functions, the images' institutional anchorage and forms of interaction. The examples range from the Greek agora, where citizens could assemble and be taken in 'at a single view', to the Nordic prime ministers' profile pictures on Facebook.

"For most men, most of the time, politics is a series of pictures in the mind", claims Murray Edelman (1964: 5). Savvy political leaders are aware that the picturing of politics is often linked to politicians and thus they tailor visual portrayals of themselves in ways that allow them to influence others and strengthen their position. Niccolò Machiavelli (1958: 99), one of the major political strategists during the Renaissance, for example, maintained that leaders do not necessarily need to have good qualities, but that it is absolutely necessary to appear to have them. This is seen in a statue of Machiavelli himself, where he is displayed as elevated, pensive and powerful. ${ }^{1}$

If we turn our gaze toward a later political leader, the former American President Theodore Roosevelt (president 1901-09) also knew how to create a favorable visual presentation. A few years before he entered politics, he was photographed on the river bank near his farm in North Dakota. ${ }^{2}$ He is shown in full hunting gear with his gun aimed at three men he had tracked down and caught after they had stolen some saddles and a boat from his property. This was the official story for many years. However, it was later discovered that, while the theft and the capture had actually taken place, the photograph had later been staged with some of Roosevelt's own employees posing as the thieves (Braudy 1986). John Corner (2000: 386) discusses this photograph as one of the earliest examples of political photography's strategic inauthenticity.
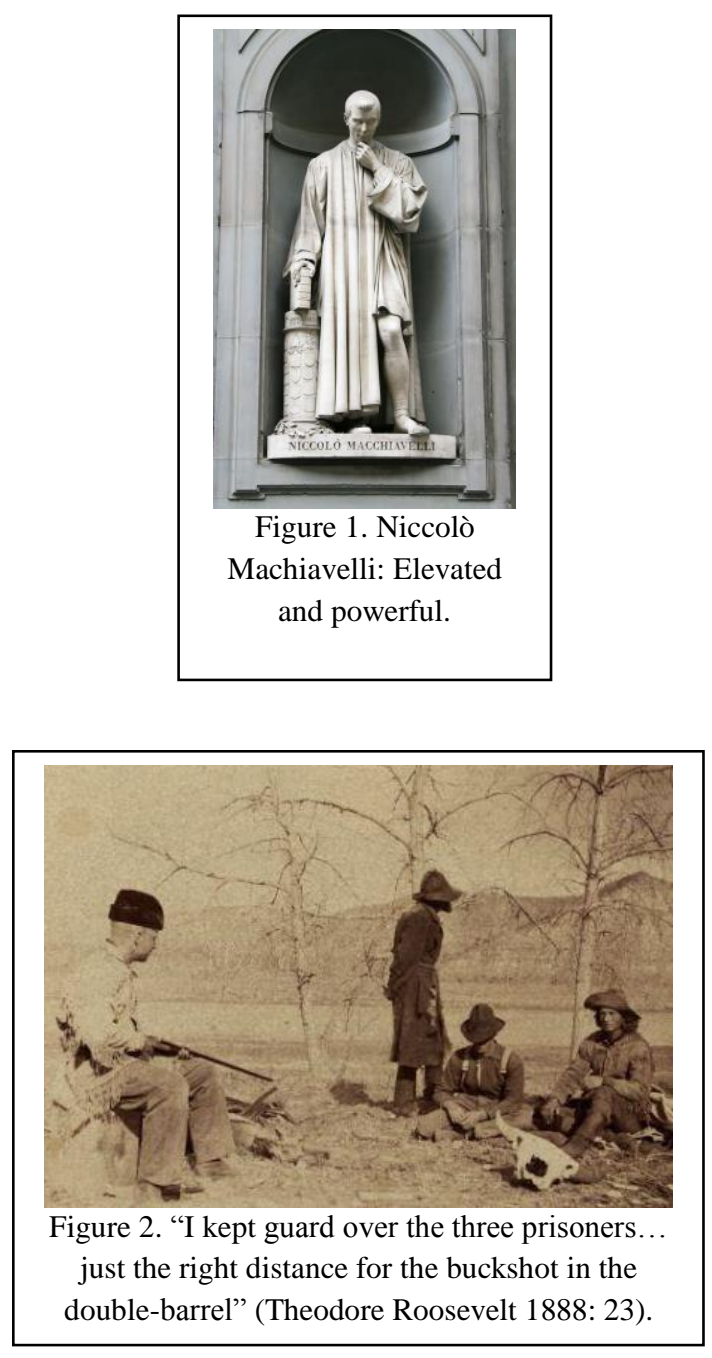
Visual representation of political elites and their power has a long tradition and, as we see from these examples, can replace qualities and recreate history. However, images can also clarify who politicians are and the values for which he or she stands (Krogstad 1999). Admittedly, most people associate political power with economic resources and authority rooted in solid institutions (Johansen 2002: 239). But power can also take a distinct shape, a physical expression (Engelstad 2010).

The physical expression of political power is related to various historically-situated instances of mediation and, later, to specific media institutions (Cook 1998). This includes a variety of tools, primarily verbal and visual. Although these often work together, it is the visual tools I discuss in this study, especially those that are associated with the politicians' physical presence. Such representation - physical appearance, posture, facial expression, gestures, clothing, and staging - can be observed in politicians' direct meetings with an audience, but also in sculptures, drawings, paintings, photographs and film/television (Krogstad 2015).

This politics of visibility, whether conveyed in direct or mediated ways, is acknowledged, but surprisingly understudied (Graber 2001, Johansen 2002, Müller 2007, Schill 2012). Researchers have repeatedly called for more studies, especially when it comes to the role and function of visual symbols within ever-new media frames and technology. As Pippa Norris (2000) claims, there is no doubt that the developments in political communication are a result of a modernization process involving constant change in the realms of politics and media, but also particularly relevant are advancements in available techniques. These allow for new forms of visibility and the experience of visibility.

Visual communication media are, however, far more than a series of increasingly more advanced technical devices that convey information from one individual to another. These media intervene in both the relationships between people and the relationships between institutions. The primary question in this article is how the constant development of new media types facilitate and create new forms of visibility and presentation in politics. In order to illuminate the political-historical lines of visual display, I begin with an overview of visual politics related to various information eras, followed by some historical examples from each era. Visual rhetoric serves as the theoretical framework for the discussion of the functions and qualities of the visible. In addition to examining what images are presented, how they are presented and with what media technology and rhetorical functions, I also examine the images' institutional anchoring and forms of interaction. The aim is a raised awareness regarding the role the visual plays in the intersection of politics, history and media.

\section{Information epochs and visibility}

John Hartley (1992) claims that the penchant for looking at people to determine political matters is not new:

Aristotle himself grounded politics upon the faculty of looking, limiting the ideal size of a state to the largest number of citizens who could assemble together and still 'be taken in at a single view'; the idea being that looking - citizens seeing each other, and seeing candidates for public office - was a prerequisite for good government and accountability. The single view, the mutual gaze of all the citizens assembled together, was a participatory, live, talking picture, as it were. (Hartley 1992: 35)

According to Aristotle the fact that citizens could see - and thus evaluate political candidates - was a prerequisite for good governance. However, the sum of these reciprocal glances became too large for what he called 'a single view'. Eventually it was possible to spread messages more efficiently and to greater numbers. 
Media theorists usually divide the media history into several information eras (Haugseth 2013, Hjarvard 2008, Rogers 1986). Jan Frode Haugseth (2013: 22) operates with four such information eras: (I) the era of writing (from $3600 \mathrm{BCE}$ ), (II) the era of printing press (from $1400 \mathrm{ACE}$ ), (III) the era of broadcast (from 1900), and (IV) the era of information (from the 1980s). These eras are often associated with particular media types, each with specific communicative possibilities concerning production, access, storage and range. In the same way that the printing press constituted a technological media revolution, photography, film, television, the Internet and digital technology have changed the ways visual political messages are being conveyed and stored (Olson 2007: 2). New media have successively facilitated new forms of action, interaction and 'publicness', each with distinct features that become even clearer when they are studied in historical perspective (Thompson 2005: 32-34).

The transitions from era to era have been gradual and these periods do have some common traits. Throughout all the eras, visual information carriers have helped to establish a more or less common political experience (Hjarvard 2008: 52). The individual information carriers are not always exclusively tied to specific eras. For example, media types from the era of broadcast still influence visual communication in the era of information, which I will show later. Furthermore, new media often copy the old but at the same time reshape them. This process, called remedialization (Bolter and Grusin 2000), involves the qualities of one medium being extended into new media. For example, photographs from the $1800 \mathrm{~s}$, with their stiff posing figures, can be seen as a 'remedialization of the painting', and film can be seen as a 'remedialization of the theatre' (Haugseth 2013: 47-48). Moreover, Facebook's profile pictures can be seen as a remedialization of the traditional election poster. The latter was one of the very early means politicians used to reach a mass audience in the public space (Vigsø 2004a, Håkansson, Johansson, Vigsø 2014). Many early forms of expression are now reworked through the multimedial Internet, with its many links and multiple views.

\section{Visual political rhetoric and communication}

Aristotle (1991) has several interesting considerations about the significance of the visual and what role it plays in politicians' attempts to generate support. In his book On Rhetoric (2006), written approximately 340 years BCE, he highlights persuasion as a key method to promote and achieve political goals. Classical rhetoric was to a large extent a political tool. In particular he expresses interest in epideictic rhetoric. This is a form of rhetoric that has its roots in what the Greeks called deiktikos, which means to strategically 'exhibit', 'show off' and 'make known' (McKeon 1987). Aristotle considers epideictic rhetoric as a separate genre, in line with deliberative (advisory) and forensic (judicial) rhetoric. Deliberative rhetoric concerns what one should or should not do and is regarded as the prototypical form of political rhetoric (Murphy, Katula, Hoppmann, Hill, Ochs 2003: 70). Forensic rhetoric is oriented towards what is right or wrong. Forensic rhetoric is usually associated with the search for truth through the examination of material signs; signs which are used to construct and substantiate earlier action sequences, for instance in criminal investigations. Forensic rhetoric is relevant in visual political communication as well, because political signs and images can also be regarded as a kind of 'evidence', as illustrated by the photograph of Roosevelt.

While deliberative and forensic rhetoric can clearly be linked to political and legal institutions, respectively, it is more unclear how the epideictic genre can be anchored. Furthermore, epideictic rhetoric is not considered as important as deliberative and forensic rhetoric. One likely reason for this is that it seems to be based primarily on emotion (ethos and pathos) rather than logic and science (Villadsen and Hansen 2005: 4). Another explanation for the neglect of epideictic rhetoric is that it is not as explicitly argumentative as the other two genres.

Even though epideictic rhetoric is neither institutionally anchored, nor grounded in logic nor argumentative in its nature, researchers have still proven how important the visual can be in politics. 
Chaim Perelman and Lucie Olbrechts-Tyteca (1971) point out how the visual can increase support for values. Similarly, Jens E. Kjeldsen (2000) emphasizes that epideictic appeals are particularly suited to uniting recipients around views, attitudes and feelings that are already shared. Such appeals are seen as a type of affirmative rhetoric which are quite easy to accomplish visually (Kjeldsen 2000: 28-29). This form of rhetoric is particularly important in times of political turbulence (Villadsen and Hansen 2005).

One basic quality of the visual is the experience of meaning it provides. Nicholas Mirzoeff (1998: 7) relates this to the phenomenological potential of sight when it comes to sensual immediacy and contemporaneousness. This quality separates the visual from more language-oriented approaches. Of course speech and text provide strong experiences too, but they are more elaborate means of communication that must be decoded sound for sound and word for word. Images are perceived more immediately and can be likened to an explosion of meaning. Images are also more effective than verbal information and text when it comes to catching the receivers' attention (Brantner, Lobinger and Wetzstein 2011, Bucher and Schumacher 2006). They are perceived and retrieved from memory more readily (Bucher and Schumacher 2006) and are very effective at translating complex information into forms that are immediately accessible (Hariman and Lucaites 2007, Perlmutter 1998, Sulkin and Swigger 2008). Moreover, they serve as an alternative route to political knowledge compared with listening and reading (Prior 2013).

In the following discussion of the cases in this article I will use a list of ten qualities - or functions that images may have in political contexts. This list is inspired by Dan Schill's (2012) summarization of the research literature in the field of visual political communication. Apart from the relatively obvious function - to document - visual images also build a politician's ethos, create identification, connect to societal symbols, evoke feelings, convey proximity, add politically advantageous ambivalence, serve as arguments, set agendas and transport their audience in time and space (Schill 2012: 122). In addition, I will show that visual communication is not only used to confirm our existing knowledge, but that it can also be used to counter the image a politician has previously been ascribed (Perlmutter and Golan 2005, Krogstad 2014).

\section{Visualizing city-states and kingdoms}

Between the years 3600 and $3000 \mathrm{BCE}$, ideas about societal and political matters were conveyed through the use of pictograms, which were an early symbolic form of writing using representational, pictorial drawings. These pictograms could be written on stone or clay tablets and spread throughout an Empire. Moreover, visual information carriers such as paintings, mosaics and artifacts made of, for example, plaster, bronze, stone played, and still play, an important role, as illustrated by the statue of Machiavelli in the article's introduction. In later times, the burden of dissemination was somewhat lightened through the use of papyrus, which could be transported more readily than stone or clay tablets. Circulation of Aristotle's own work, for example, was eased by employing papyrus imported from Egypt (Haugseth 2013).

When considered as media, i.e. as 'information sharing social platforms', these forms of communication were limited both in terms of content dissemination and range (Haugseth 2013: 17). For most people throughout history, and particularly for those in sizable communities, their political leaders have been invisible. To the extent that the leaders were visible, much of their power rested on what John B. Thompson (2005: 36) calls 'their physical appearance before others in contexts of copresence'. This condition persisted up to late medieval and early modern times - and even later in other parts of the world. In these live demonstrations the leaders' body, bodily gestures and clothes were central. 
Previously, I mentioned how 'the single view' affected politics in the city-states of antiquity. When the citizens of the Greek city-state gathered in order 'to hear and see' their political leaders, they did so in a town square, on a hilltop or perhaps in an amphitheater (Johansen 2002: 30). It was in this agora decisions were made. Here one could experience the leaders live, however these live assemblies were commonly restricted to a maximum of a few thousand people. This was the limit of their publicness. While word of what happened in such public assemblies could admittedly be spread throughout the Empire, both verbally (for example, via runners), and in writing (for example, on papyrus or parchment), it was a relatively time consuming exercise.

The single view also dominated in the early European kingdoms, in which an inherited form of political leadership was typical. Also in these kingdoms visual information exchange was to a large extent characterized by co-presence. Until the printing industry had matured, only a few of the king's associates - family, friends, the court, staff at the court and the social and political elite - could see and experience him at close range. Thus he was out of reach for most people. He could, of course, be seen at large events such as victory parades, coronations and funerals (Thompson 2005: 36). Although the king's presence at such events was concrete and physical, formal ceremonies still provided a certain distance between him and the people. According to Gudmund Hernes (1989), such a display of distance is part of the aesthetics of power. Power is linked to 'podiums and platforms, thrones and tribunes'. Powerful people distance themselves by using 'walls and fences, stairs and portals', are protected by 'guards and escorts" and are assisted by 'chamber servants in livery' (Hernes 1989: 9192).

An artistic expression of the aesthetics of power is a well-known painting of the French Sun King Louis XIV (1638-1715), painted by Rigaud in 1701 (Image 3). Standing on a raised platform, the king looks at his spectators with a serious face. Distance is also conveyed through his clothing, which makes him look both broader and - thanks to his high heels and impressive wig - taller than he is. The exclusivity of the clothing helps to reinforce the distance: here are layers of silk, lace, brocade velvet and fur. From the end of the Middle Ages, the right to wear such expensive and colorful garments was strictly regulated, as aspiring groups were forbidden from using special types of fabrics and colors that the aristocracy - or the king - should have the sole right to use (Daloz 2010: 65).

The painting probably bears a certain resemblance to the king himself, and thus has some documentary value. In addition it conveys an argument about 'greatness', which, in turn, can evoke certain kinds of feelings among the viewers - depending on the cultural and historical context. The king's direct gaze in the image is interesting. According to Gunther Kress and Theo van Leeuwen (2010) it was not until the 1400s that painters portrayed people with eyes directed at the viewers. According to

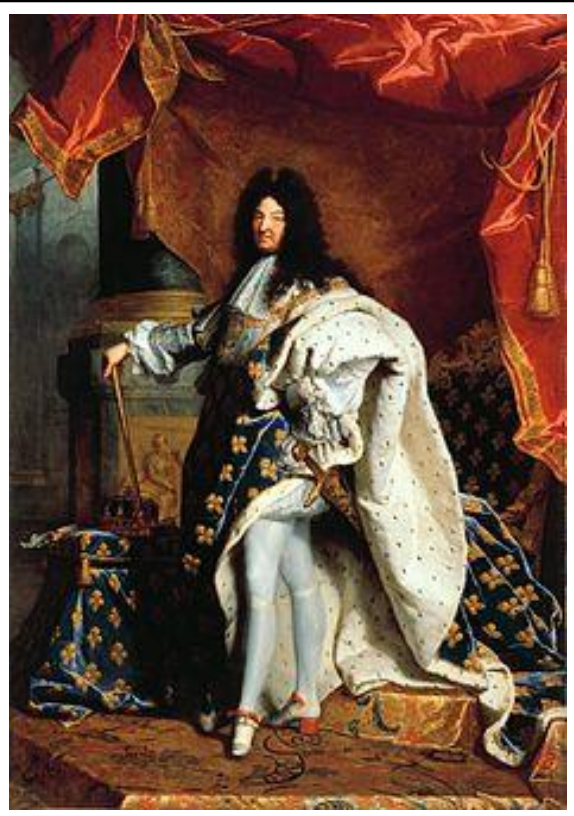

Figure 3. From his elevated platform and high-heeled shoes Louis XIV looks down at his viewers. Kjeldsen (2008), this kind of gaze is a direct inquiry that rhetorically helps to catch the viewer's attention.

Power and influence during the Sun King's time was in large part determined by the proximity one had to the king's person and body. His body was worldly and visible, but it also had a backstage, as well as a more symbolic dimension. Articles of clothing, wigs and other equipment required servants, 
and his most intimate bodily processes were closely surveilled. At the same time he drew his legitimacy from a higher power, the divine. Both parts were integrated into his body, which was both 'natural' and 'divine'. Ernst H. Kantorowitcz (1957) labels this double logic 'human by nature and divine by grace', and argues that it was particularly evident in early French kingdoms. In the book The King's Two Bodies he asserts that it was the kingdom, not the king himself that was sacred, something that was illustrated by the phrase, 'The king is dead. Long live the king'. The symbolic kingdom, of which Image 3 is a visual representation, trumped the earthly. The elevated and divine served as a symbol of the king's institutional power and his right to rule. This forceful pairing of politics and religion created a huge symbolic reservoir. The visual could effectively be used to build leadership, institutions, and - with time - nation states.

\section{Print, image and nation-building}

As the era of print evolved, leaders, be they princes, kings, or politicians, were increasingly visible regardless of their physical presence in front of an assembled audience (Thompson 2005). The art of print gave leaders new opportunities, both to multiply official decrees and to distribute favorable pictures and descriptions of themselves. For example, Louis XIV, who lived in the transition phase between the era of the writing and the era of the printing press, was what we today would call an effective image-builder (Burke 1992). He used the new print opportunities based on woodcuts, etchings and engraving, which allowed for drawings and descriptions of him to be published in newspaper columns about the monarchy in The Gazette de France and Mercure Gallant (Thompson 2005: 37).

With print, pictures of leaders were spread to a larger and more widely dispersed circle of people than previously. The experience of - and in many respects the identification with - powerful leaders was no longer based primarily on physical appearance before others in contexts of co-presence. Through the new means of visual communication and storage, audiences could be 'transported' in time and space. These were the first steps toward a publicness based on what Benedict Anderson (1983) calls 'imagined communities' which are explicitly tied to the development of print. Print gave impetus to the formation of an abstract 'present' and facilitated political affiliation to larger and more abstract entities and systems (Anderson 1983). The gradual emergence of a public allowed for the development of a new method for the construction of political and cultural communities - nationbuilding. In addition to the leaders themselves, official ceremonies and what Eric Hobsbawm and Terence Ranger (1983) call memorials (lieux de mémoire) - public monuments, flags, folk costumes, and certain colors - functioned, and still function, as visual support for such nation-building projects. In as much as a nation itself is invisible - an almost Platonic idea - it must be displayed in one way or another. As the American political philosopher Michael Walzer (1967: 194) claims: 'A state or a nation must always be personalized before it can be seen, symbolized before it can be loved, imagined before it can be conceived'. Primarily because it is the concrete politicians who, through a combination of verbal and visual rhetoric, convey and perform politics, Walzer underscores the value of personalized politics that rhetorically build on image, identity, and emotion.

The rhetoric of nation-building is also of interest to Norwegian researchers. Anders Johansen (2002) describes how the aggrandized, patriotic speech style typical in the early 1800 s, when the Norwegian constitution was written, was accompanied by large and idealized body language. Furthermore, he describes how the rhetoric went into a quieter phase in the mid 1800s, when the politician intellectuals' dry, meticulous and visually stingy style helped to solidify the dominance of an elevated and exclusive elite. However, according to Johansen and Kjeldsen (2005: xxxii-xxxii), corporeal manifestations returned toward the end of the 1800 s, when the so-called folk speakers' simple, vivid and emotionally enthusiastic rhetoric and gestures not only rejuvinated such speeches, but also contributed to the expansion of democracy by letting the people themselves speak. 
In addition to the gestures and facial expressions, the garments that clothed the physical body of the politician were important. Several researchers have pointed out how clothing was associated with the development of the Norwegian nation state and the creation of a separate national identity (Oxaal 2003, Pettersen 2004).

In the early 1800 s Norwegian politicians wore civil uniforms and clothes that were representative of their status, be it civil servants, land owners, merchants or farmers. For instance, the largest group, civil servants, wore French inspired uniforms with long 'justaucorps' in red, green, yellow and gold combined with a high double folded collar, tight-fitting white breeches, triangular hats and ornamental sword (Oxaal 2001) (Image 4). ${ }^{3}$ After the loss in the Napoleonic Wars and the split of Norway and Denmark these uniforms were no longer considered politically correct (Pettersen 2004). In a new uniform regulation, issued in 1815, the colorful justaucorps were rejected in favor of shorter coats in gray or black, and the breeches were replaced with fulllength trousers. These changes were symbolically charged and served as a visual-political confrontation with the upper class. The new outfits were seen as symbols of the French revolution and its democratic ideas of liberty, equality and fraternity (Pettersen 2004: 60).

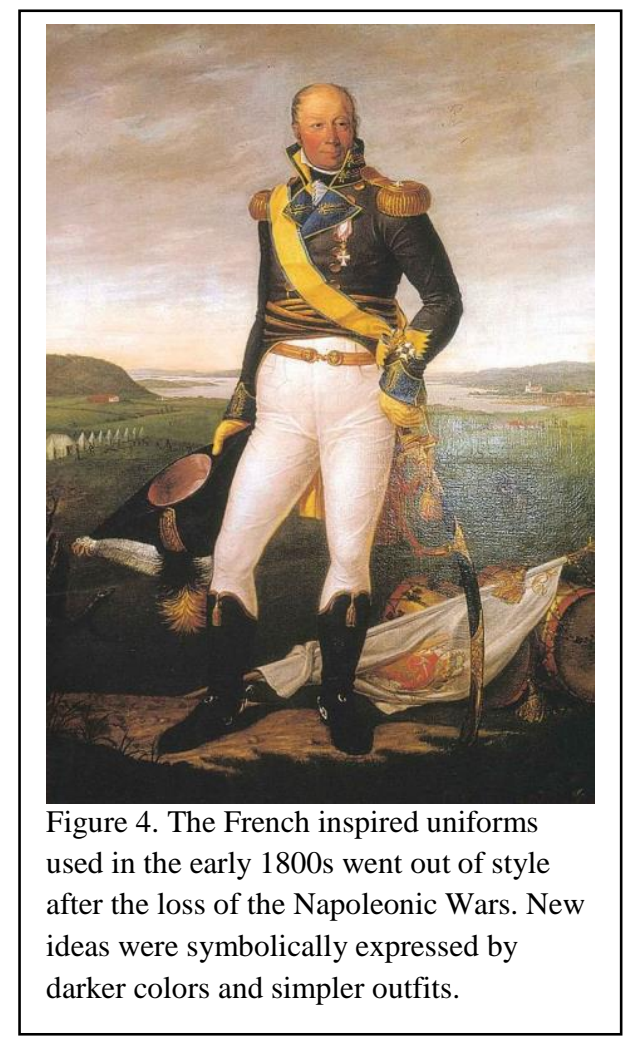

Eventually a more unified dress code emerged in politics: the modern 'three-piece black suit'. According to Anne Hollander (1994) this suit was developed during the course of the 1800s as a political demonstration against the lavish use of color and fabrics in aristocratic clothing. The dark suit made rank differences invisible, subdued individual expression and was considered rationality's victory over feudal society (Hollander 1994: 109). With the advent of the suit, which has barely changed in 150 years, one no longer required servants to get dressed. In our time it is easy to forget that the suit - in somewhat the same way as the more folksy speech style - visually and symbolically marked the expansion of democracy.

\section{Simulated presence and credibility in the time of broadcasting}

We have seen that political leaders' ceremonies, platforms, speech styles, gestures, gazes, clothes and shoes raise them above the people, both literally and symbolically (Meyrowitz 1986). Much of this changed in the era of broadcasting (from 1900), especially when the television, with its extensive reach, became a main arena for political mass communication. Through many television formats viewers are allowed in-depth access to politicians. In this respect, viewers approach - if not the completely private sphere - at least the hybrid sphere that is located between the public and the private (Meyrowitz 1985, Corner 2003). It is not only the border between the front stage and the back stage that has changed; the television set also changes the dimensions of time and space, interaction and range. Thompson summarizes as follows:

One no longer has to be present in the same spatial-temporal setting in order to see the other or to witness an action or event. The rise of this new form of mediated visibility has transformed the relations between visibility and power. Thanks to mediated visibility, 
political rulers are able to appear before their subjects in ways and on a scale that never existed previously. (Thompson, 2005: 35)

The live images on television facilitate new types of communication and also present new requirements for visual representation. The large and emotional gestures of folksy speakers would seem out of place in this medium (Johansen, 2002). Television reduces the 'distance' between the politician and the public such that it is reminiscent of the distance between close friends. Viewers at home in their own living rooms are offered a 'simulated' and a 'de-spatialized' presence (Thompson 2005), also when the events covered have taken place previously. Stig Hjarvard (2005) calls this sense of interaction 'mediated quasi interaction'. However, this interaction, largely based on the live pictures television gives us, is also important. Close-ups, especially of the politicians' faces, invite a thriving type of interpretation when it comes to small signs of authenticity and inner life. They may also point to something beyond politicians' calculated appearances. To many, such images are starting points to assess the credibility of a politician. Television is the medium for the minimal nuances. 'On television sometimes microscopic details make a big difference: a single tear, a resignated expression, lightly raised eyebrows' (Johansen 2002: 25). This can lead viewers to feel, 'Yes, we know them now. They have not only become visible, but also almost transparent: we believe we can see if they have "contact with their own feelings", and really mean what they say' (Johansen and Kjeldsen, 2005: 506).

For a politician, the focus is still on presenting oneself as legitimate and credible, as it was for Machiavelli, Louis XIV, Roosevelt and former Norwegian politicians. But how does one do that? The requirement to 'be yourself' was not dwelled upon much in antiquity (Kjeldsen 2004), even though the art of statesmanship also entailed a handling of one's political self and "playing off the "outer" against the "inner" (Corner 2000: 387). Nor did the great Norwegian speakers appear as their ordinary selves; they rather performed in public and often with theatrical means (Johansen 2002). This was not something to hide. Theatrical means were not, however, used in more private contexts. Still the speakers were regarded as credible and consistent because they operated in two different arenas that were not seen as connected (Johansen 2002).

In the television age, however, politicians' performances are to a greater extent based on how well private life is integrated into the public role. The demand for authenticity has increased. According to Kjeldsen (2004:121) a politician should appear to be anything but prepared, trained or staged. Rather, the point is to appear spontaneous, genuine, personal and emotional. A problem connected to this is that politicians behave differently depending on the situation, who they talk to, who is present, etc. Cameras capture this, and preserve it. Compilation of such sequences may later show that politicians behave differently in different contexts, which may give the impression of inconsistency or perhaps even dishonesty. Given that mystification and awe are often nourished by distance and limited availability (Meyrowitz 1985), it is easy to see how television's in-depth and continuous inspection can lower political leaders to a more prosaic level.

What I previously termed instances of mediation between politicians and their constituents have, with the broadcast age, evolved into becoming independent, rule-oriented media institutions that form an important part of public opinion. Timothy E. Cook (1998) links this especially to the media's power to set the agenda. The media no longer function as a mouthpiece for politicians, as they previously did in the time of openly partisan journalism. The media have become independent agenda setters, interpreters, communicators and, indeed, investigators, who first and foremost define their obligations in relation to the audience. The institutionalization and the apparent strengthening of the media at the expense of politicians is, according to Peter Esaiasson and Nicklas Håkansson (2002), one of the greatest power shifts that has taken place during the course of the 20th century. With this the character of political leadership changed and politicians became increasingly vulnerable. They had to adopt the media's own thinking and behavior as a counter strategy (Krogstad 2004). It became vital to convey the correct, and of course also the most beneficial, images of themselves. This resulted in an entire industry of professional helpers (media consultants, advertising agencies, stylists, etc.) who could 
offer their knowledge of media, branding, presentation techniques, clothing, and so forth. Careful choreography of their image has become a tool politicians use to retain control over what is released (Krogstad 1999: 16). However, to the extent politicians adapt to the logic of the media, the media in turn adapts to the politicians' methods by setting new and more sophisticated requirements for them, an effect Kent Asp (1986) calls the spiral of mediatization.

The era of broadcast has had a major influence on how politicians display themselves as legitimate and credible in the public sphere, an influence that has not ceased with the introduction of the era of information. How politicians display themselves as legitimate and credible has changed in several ways. This can be observed especially since the entry of women into politics. As a female leader, how does one go about expressing authenticity and leadership, when the political traditions to such a great degree are designed by and for men? Culture also plays a role and is often closely intertwined with gender. In a comparative study of political leaders in France and Norway, Krogstad (this author) and Storvik $(2007,2010)$ found that political leadership ideals in France are orientated towards what Max Weber (1968) calls charismatic authority exhibited through what we call 'effortless superiority'. Norwegian politicians, however, gravitate first and foremost towards a rational-legal dimension, as well as a more subtle form of charisma we call 'low key charm'. French politics are described as a political cocktail consisting of heroism, conquest, passion and drama. In contrast, the Norwegian political leadership ideal, which we call 'the charisma of the ordinary human being', is characterized by a down to earth orientation and pragmatism. These ideals serve as the basis for completely different leadership styles, also visually.

In particular, it has been interesting to see how newcomers in politics, i.e. women leaders, maneuver in comparison to the already established leadership styles (Krogstad and Storvik 2012). Women leaders in France had to find other and more moderate ways to express leadership than the masculineoriented 'seductive hero'. At the same time, female leaders in Norway risked disappearing visually if they applied the 'conspicuous modesty' (Daloz 2010) ideal their male colleagues had long used. Although this ideal probably eased Norwegian women's entry into politics, they had to show themselves as powerful in order to not completely fly under the political radar. For instance, in 2008 a British newspaper coined the term 'the formidable blond pitbulls' to describe the many Norwegian female party leaders at that time. We further found that the existing stereotypical images of female politicians - mothers, tough women, historical figures, glamorous women, colorful women, seductresses, playful ironic women - have different cultural connotations in the two countries, and that they are therefore used very differently by the female leaders. Political visibility repertoires are thus both cultural and gendered. But they are not necessarily narrower for women than men, as the next example shows.

During the campaign leading up to the Norwegian Parliamentary election in 2013 the leader of the Conservative Party and later Prime Minister, Erna Solberg, appeared in a photograph published in one of the main newspapers (Dagbladet's Magasinet July 13, 2013). ${ }^{4}$ In the photo (Image 5) she is preparing food in a far from tidy kitchen.

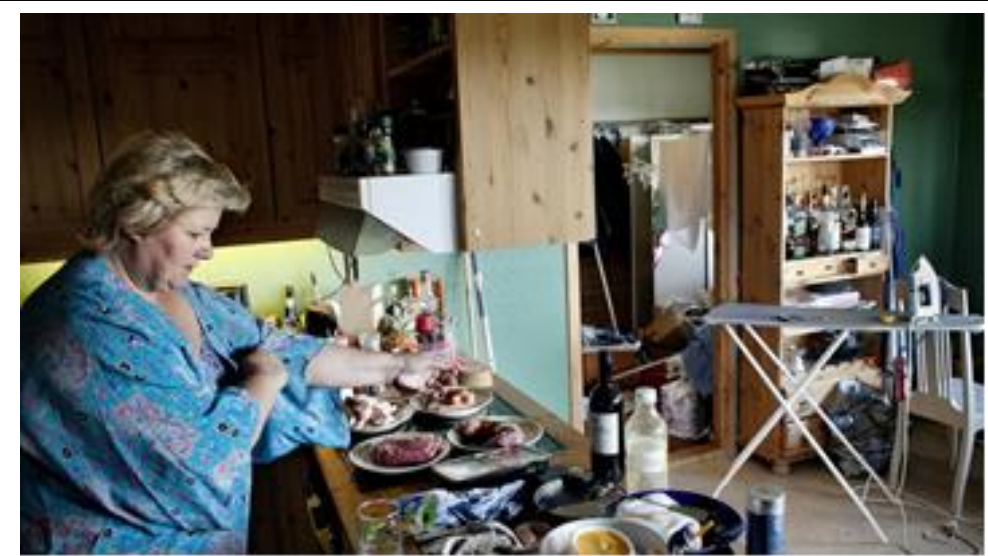

Figure 5. At the home of Erna Solberg, leader of the Conservative party in Norway, a few months before she was elected Prime Minister. Would she have been elected Prime Minister in France? 
On a general level, one can say that Solberg's informal presentation in this photo is in line with the Norwegian orientation towards equality and 'folksiness' (folkelighet) (Krogstad 2015). But the photograph generated a certain amount of surprise since the folkelighet in this case came from a conservative party leader. In the debate that followed, there were many who thought that Solberg's image was a calculated attempt to appeal to a broader section of the population. There was suspicion that the kitchen was styled in advance, in a conscious attempt to increase popularity. Solberg strongly denied this and claimed that her advisors would have 'freaked out' had they known that the photographer would take photos inside her home. ${ }^{5}$ Whether she intentionally allowed the photographs in an effort to show how down to earth she is or not, the photo never-the-less functioned as a tool of visual political influence. It afforded something other than confirmation of what most would expect from a conservative female leader. Such images can possibly extend a politician's reach and/or expand their support, as long as the image only serves to wake up the electorate and not to scare them away.

\section{The information age: new visual possibilities}

The information age (from 1980) represents yet another era in political visual communication. While television, the most central media in the broadcasting age, was a facilitator for experiences with others at a social distance, computers facilitate interaction via keyboards and screens at a personal distance. For the first time in history, ordinary people have the opportunity to publish what they want to a broad public, more or less free from censorship and editing (Rasmussen 2003). With this, the distinction between private and public becomes even more blurred. A variety of digital publics have emerged. Virtualization of society's institutions has made it possible to take part in these public arenas independent of time and place. The Internet conveys an abundance of visual messages and penetration of this around-the-clock global information myriad requires cleverness. But there are examples of politicians taking back some control over the visual information being released. Furthermore, they use digital tools for their own purposes by, for example, capitalizing on the ability of such digital tools to lower the threshold of social group formation (Shirky 2008: 14). It is the use of images in social media, more specifically politicians' profile pictures on Facebook, I explore in the following example.

Facebook profile pictures may at first glance seem small, flat and insignificant. But these images represent a form of conscious, strategic and professional communication designed for media exposure and influence. The pictures are part of a politician's personal and political branding and portray the political self as beneficial and as flattering as possible. The political leaders' faces and bodies, their facelook, are not mediated by journalists or editors before they reach the public. Because politicians and party strategists control the representation, communication through Facebook profiles bears a resemblance to earlier partisan journalism and sometimes it borders on presenting the politicians as absurdly successful.

Facebook, like other social media, has an architectural structure that constantly adapts to changes and is formed by usage (Hoff-Clausen 2008: 75). Profile pictures require more than a pure image reading, as they are part of a multimodal and dynamic context unlike image presentation in other static media. The profile picture itself is given a key position: at the top left. The image is used as an avatar in other parts of Facebook as it introduces all the textual updates. Facebook also provides the ability to like and to comment, which reinforces Facebook as an interactive medium. In condensed photographic form, profile pictures give politics a concrete human expression. They can be seen as synthesized politics in visual, personalized form (Krogstad 2013, 2014). Images convey contact between political leaders and the people, even though the contact is by proxy, i.e. contact via vicarious visual representatives. 
In Table 1, I give an overview of the profile pictures of the five Nordic prime ministers in 2016. In addition to political affiliation, the table shows degree of formality, facial expressions, gaze, camera distance and camera angle. Together, these dimensions provide a clue as to what politicians display and how.

Table 1. Profile pictures of Nordic Prime Ministers, Facebook, November 2016.

\begin{tabular}{|c|c|c|c|c|c|}
\hline $\begin{array}{l}\text { Politician/ } \\
\text { country }\end{array}$ & $\begin{array}{l}\text { Erna Solberg, } \\
\text { Norway }\end{array}$ & $\begin{array}{l}\text { Lars Løkke } \\
\text { Rasmussen, } \\
\text { Denmark }\end{array}$ & $\begin{array}{l}\text { Stefan Löfven, } \\
\text { Sweden }\end{array}$ & $\begin{array}{l}\text { Juha Sipilä, } \\
\text { Finland }\end{array}$ & $\begin{array}{l}\text { Sigurður Ingi } \\
\text { Jóhannsson, } \\
\text { Iceland }\end{array}$ \\
\hline $\begin{array}{l}\text { Profile } \\
\text { picture }\end{array}$ & & & & & \\
\hline Party & $\begin{array}{l}\text { The Conservative } \\
\text { Party }\end{array}$ & The Liberal Party & $\begin{array}{l}\text { The Social } \\
\text { Democratic Party }\end{array}$ & The Center Party & The Progress Party \\
\hline $\begin{array}{l}\text { Style of } \\
\text { dress }\end{array}$ & $\begin{array}{l}\text { Formal: dark blue } \\
\text { suit jacket, clearly } \\
\text { wearing makeup }\end{array}$ & $\begin{array}{l}\text { Very formal: black } \\
\text { suit jacket, white } \\
\text { shirt, dark tie }\end{array}$ & $\begin{array}{l}\text { Formal: dark blue } \\
\text { jacket, light blue } \\
\text { shirt and red tie }\end{array}$ & $\begin{array}{l}\text { Somewhat } \\
\text { informal: dark } \\
\text { sweater, light blue } \\
\text { shirt with } \\
\text { unbuttoned top } \\
\text { buttons }\end{array}$ & $\begin{array}{l}\text { Very formal: black } \\
\text { suit jacket, white } \\
\text { shirt, dark tie }\end{array}$ \\
\hline $\begin{array}{l}\text { Facial } \\
\text { expression }\end{array}$ & Smiling & Faintly smiling & Smiling & Smiling & Broadly smiling \\
\hline Gaze & Eye contact & Eye contact & Eye contact & Eye contact & Eye contact \\
\hline $\begin{array}{l}\text { Camera- } \\
\text { distance }\end{array}$ & Very close & Close & Medium close & Medium close & Close \\
\hline $\begin{array}{l}\text { Camera- } \\
\text { angle }\end{array}$ & $\begin{array}{l}\text { Weak bottom-up } \\
\text { angle }\end{array}$ & $\begin{array}{l}\text { Weak bottom-up } \\
\text { angle }\end{array}$ & Frontal angle & Bottom-up angle & Bottom-up angle \\
\hline
\end{tabular}

The first thing that struck me when viewing the profile photos next to each other, was how absurdly similar the politicians appear. In their profile pictures the prime ministers are not engaged in any activity, there is minimal context and four of the five are dressed in the politicians' premier prop - the dark suit (including the female Prime Minister, Solberg). All can be said to smile to some extent, all look straight into the camera, and all are depicted with head and upper torso. The trick, it appears, is to 'do nothing, and still be everything - for all' (Vigsø 2011). This admittedly also applies to two of the previously shown politicians - Machiavelli and Louis XIV. However, they both show their whole bodies, are placed on elevated platforms and look down upon their viewers with serious facial expressions. Although four of the five profile pictures of the Nordic prime ministers also are angled from the bottom-up, the photos seem to convey a higher degree of proximity, particularly because of the close camera distance and smiling faces.

Some researchers have suggested that epideictic rhetoric advances no argument and thus cannot be considered rhetorical (Andersen 1995:30). However, the profile pictures of the Nordic prime ministers give several examples of argumentation. When reviewing the visual elements we see how clothing and posture communicate seriousness or relaxation, the latter exemplified by the Finnish Prime Minister's relatively informal clothing and playful pose. We also see how smiles suggest friendliness, 
how the camera creates the experience of closeness, and how bottom-up or frontal camera angles elevate the politicians to varying degrees (Kress and van Leuwen 2010). It is their faces, not to mention their direct gazes, that create contact with the viewer.

The direct gaze is not, however, common to all profile images. In Solberg's previous profile photo she had an upturned gaze; a gaze many would associate with something visionary (see far left photo in Image 6). In addition, the picture was taken from a bottom-up camera angle. Although this form of presentation is not unusual in other parts of the world, this type of political display is very rare in the relatively equality-oriented Nordic countries (Kjeldsen 2008). In one of Barack Obama's profile pictures from the 2008 US election campaign he uses the same pose, with his head surrounded by a soft sky-like blue halo. ${ }^{6}$ UK's Theresa May appears in a somewhat similar pose in her profile picture in 2017. ${ }^{7}$ These photos remind us of Alberto Korda's iconic photo of freedom fighter Ernesto 'Che' Guevara. ${ }^{8}$ Thus, this type of look and pose has a deeper cultural and political resonance.
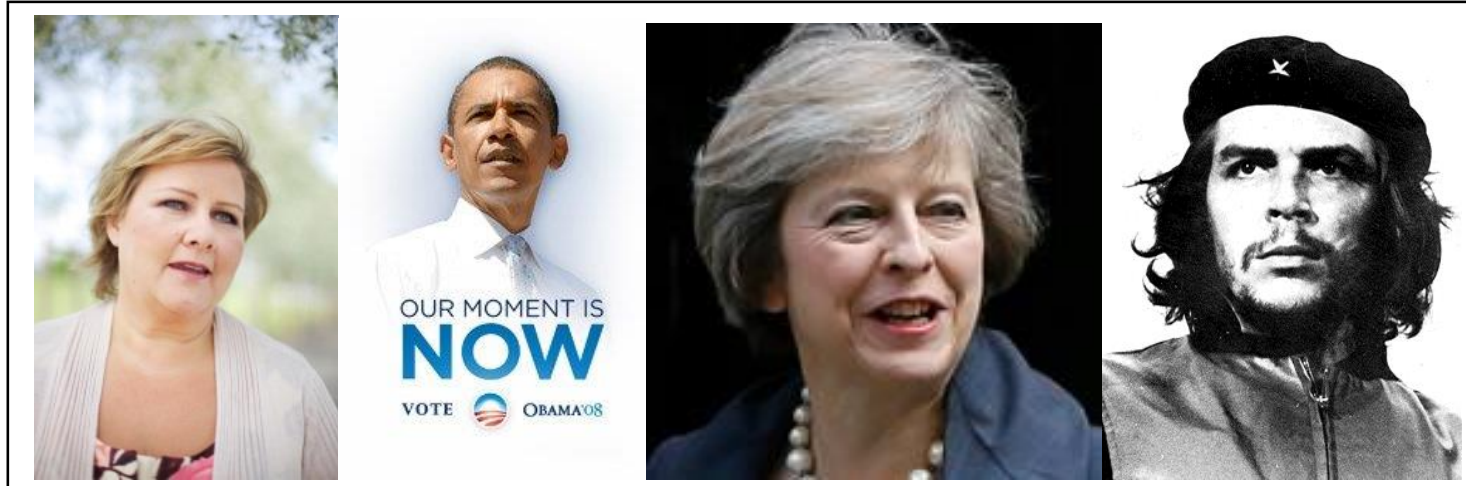

Figure 6. Prime Minister Erna Solberg's upturned gaze and lifted head have distinct political references.

The profile pictures of Solberg and May do not feature the same serious determination as seen in the photos of the two men. The women smile - although Solberg only slightly. However, a question that can be asked of all four is whether they are visionary or whether they, as Machiavelli emphasized, first and foremost look visionary?

\section{Discussion}

Drawing on the previously mentioned visual communication theories, I attempt here to summarize the examples in this article. As Kantorowitcz' (1957) analyses of the French kingdoms emphasized, the symbolic role of a leadership is important. However abstract or short-lived any political leadership may be, it has to be expressed in some way or another. Forensic and - not least - epideictic rhetoric are the means at hand. Also Schill's list of the ten qualities that political images may have is activated in this discussion.

An obvious quality of the visual is linked to documentation - visual 'evidence'. An abundance of words would have to be used in order to describe the politicians portrayed in this article and those words would still not convey exactly the same expression. Admittedly, images can distort or misrepresent qualities. For example, the painting of Louis XIV was probably both magnifying and beautifying and the photograph of Roosevelt can be seen as an example of strategic inauthentisity 'combining the mythic resonance of emblematic painting with the documentary claims of the lens' (Corner 2000: 386). Still, visual media let us, at least partially, inspect how political leaders look or have looked. The requirements and expectations for political display have, of course, varied over time. For example, while most statues from antiquity were most often oriented towards the representation 
of character types rather than of individuals, the television is largely geared toward the documentation of the personal inner through, for instance, exposing cracks in the façade. Meanwhile political identity on the Internet is performative in the sense that real bodies no longer work as guarantor of a 'true' or 'real' self. Still, present day leaders do not seem to escape recurrent discussions about their authenticity and whether or not their bodies and identities can be considered 'real' (Slater 1998).

The visual is central in ethos-building processes. In the same way the logo is a condensed expression of a party's politics and thus ensures continuous recognition (2004b Vigs $\varnothing)$, the ethos of a king or a prime minister can be a condensed expression of leadership. Through their bodily display, leaders will - either directly or visually mediated - be able to personalize and highlight political entities, be it groups, parties or nation states. In this way they will connect citizens to societal symbols. More concretely, this happens through bodily expressions such as style, posture, gestures and staging. We have seen that even clothing, which is often regarded as a superfluous sign, can indicate a stance, for example, either for or against democracy. Two key qualities images have are their capacity to create identification and aid in emotional appeals, which are undoubtedly central to nation-building processes. If voters experience (equality with or) proximity to the politician, it can lead to political action ranging from a click on a 'like' button, to putting a ballot in the election urn, to full political participation.

The ambiguity of certain leaders' images, that is, whether the images work implicitly or latently, may create opportunities for politicians to appeal to a diverse electorate. For example, a top leader's image will of course signify leadership, but at the same time it can be constructed to make the leader seem down to earth, as illustrated by the photograph of Erna Solberg in her home. Images can also serve as arguments, often in the sense of suggestions rather than precise allegations, which characterize epideictic rhetoric. The Nordic prime ministers' profile pictures convey suggestions about the visionary (Erna Solberg, Image 6), the serious (Lars Rasmussen Løkke), the formally friendly (Stefan Löfven, Sigurður Ingi Jóhannsson) and the informally cheerful (Juha Sipilä). Profile pictures ensure that the leaders are visually present in the voters' consciousness and thus continuously set the agenda. Because of technological innovations, pictures and film have the capacity to transport their audience in time and space as they can bring the politicians - by proxy - right into people's living rooms. In the Internet age, voters can look at and comment on most of the world's politicians from home, sitting in their pajamas in front of a computer or iPad at midnight.

Kjeldsen (2000) has pointed out that the visual is particularly suited to confirm what recipients already believe. Politicians' appearance will then evoke something that already exists in the voter. However, the visual can also be used to counter or break with a politician's qualities and values. For example, when a politician is being criticized for being boring, administratively-oriented or shortsighted, she can try to score political points by presenting herself in a colorful dress and with a visionary upturned look. When a female Prime Minister uses a dark suit jacket, this can be seen as surfing on the established position this classic male garment has had during the last 150 years. She could attempt an even broader appeal by combining the dark suit with cheeky and colorful leopardprint shoes, as Theresa May did when she was appointed British Prime Minister in 2016.

\section{Conclusion}

Political power must be expressed in one way or another and words are obvious in this context. Some have even maintained that the mouth is a politician's physiological centre (Bomann-Larsen 1989). But the visual also plays a role, either alone or in combination with words. In this article I have, on the basis of four information eras, discussed examples of how politicians express themselves visually. They do this either live, for instance at the agora or at royal ceremonies, or they do it through a variety of media (statues, pictograms, paintings, photographs, television, Internet). In the above discussion of the qualities of images, I summarized what is conveyed in this article's examples, how it is conveyed 
and with what rhetorical potential. However, a politician's display, whether live or mediated, also relates to media's technological development, institutional relations and interaction.

In the first information era participants in relatively small assemblies were able to see and assess politicians' representations directly 'in a single view'. Information channels, such as pictograms and writings on clay tablets, stone, papyrus and parchment, played a certain role in the exercise of power in society, but were not institutionalized. Dissemination took time and it was not until the next era, the age of the printing press, that mass mediation developed. After being subordinate to other institutions, such as the religious, independent media institutions gradually surface. In parallel, there is a gradual democratization and evolvement of the public. In the broadcast age politicians' mediated visibility enables them to appear before their subjects 'in ways and on a scale that never existed previously' (Thompson 2005: 35). The political publicness absorbs many of the manners and ways that characterize the private sphere where we are visibly present for each other, and thus a hybrid sphere emerges. In the information era digital applications and media are made available on a variety of platforms. Institutions can no longer be localized to specific places, but become virtual. Interaction is still simulated, but there are new dialogical and virtual interaction forms. This means that politicians, in this latest phase of the history of display, can reach out to their voters in new ways, making use of these shifts in the relationship between private and public, and between politics and media. 


\section{References}

Anderson, B. (1983), Imagined Communities: Reflections on the Origin and Spread of Nationalism, London: Verso.

Andersen, Ø. (1995), I retorikken hage, Oslo: Universitetsforlaget.

Aristoteles (1991), On Rhetoric: A Theory of Civic Discourse. Transl. by G. A. Kennedy. Oxford: Oxford University Press.

Asp, K. (1986), Mäktiga massmedier. Studier i politisk opinionsbildning, Stockholm:

Akademilitteratur.

Bolter, J. D. and R. Grusin. (2000), Remediation. Understanding New Media, Cambridge: The MIT Press.

Bomann-Larsen, T. (1989), Den perfekte politiker, Oslo: J.W. Cappelens forlag.

Brantner, C., K. Lobinger and I. Wetzstein (2011), 'Effects of visual framing on emotional responses and evaluations of news stories about the Gaza conflict 2009', Journalism and Mass Communication Quarterly, 88, pp. 523-540.

Braudy, L. (1986), The frenzy of renown: fame and its history, Oxford: Oxford University Press.

Bucher, H.-J. and P. Schumacher (2006), 'The relevance of attention for selecting news content. An eye-tracking study on attention patterns in the reception of print and online media', Communications: The European Journal of Communication Research, 31, pp. 347-368.

Burke, P. (1992), The Fabrication of Louis XIV, New Haven: Yale University Press.

Cook, T. E. (1998), Governing with the News: The News Media as a Political Institution, Chicago: University of Chicago Press.

Corner, J. (2000), 'Mediated personae and political culture', European Journal of Cultural Studies, 3: 3, pp. 386-402.

Daloz, J.-P. (2010), The Sociology of Elite Distinction, New York: Palgrave Macmillan.

Edelman, M. (1964), The Symbolic Uses of Politics, Chicago: University of Illinois Press.

Engelstad, F. (2010), Maktens uttrykk. Kulturforståelse som maktanalyse, Oslo: Universitetsforlaget.

Esaiasson, P. and N. Håkansson (2002), Besked ikväll! Värnamo: Fälth and Hässler.

Graber, D. A. (1990), 'Seeing Is Remembering: How Visuals Contribute to Learning from Television News', Journal of Communication, 40: 3, pp. 134-55.

Hariman, R. and J. L. Lucaites (2007), No caption needed: Iconic photographs, public culture, and liberal democracy, Chicago: University of Chicago Press. 
Hartley, J. (1992), The Politics of Pictures: The Creation of the Public in the Age of Popular Media, London: Routledge.

Haugseth, J. F. (2013), Sosiale medier i samfunnet, Oslo: Universitetsforlaget.

Hernes, G. (1989), 'Maktens estetikk'. In H. Fink (ed.), Arenaer. Om politik og iscenesattelse, Aarhus: Aarhus Universitetsforlag.

Hjarvard. S. (2005), Det selskabelige samfund - essays om mennesker og medier, Frederiksberg: Samfundslitteratur.

Hjarvard, S. (2008), 'The Mediatization of Society. A Theory of the Media as Agents of Social and Cultural Change', Nordicom Review, 29: 2, pp. 105-134.

Hobsbawn, E. and T. Ranger (eds.) (1983), The Invention of Tradition, Cambridge: Cambridge University Press.

Hoff-Clausen, E. (2008), Online Ethos - Webretorik i politiske kampagner, blogs og wikis, Fredriksberg: Samfundslitteratur.

Hollander, A. (1994), Sex and suits, Sparkford: Claridge Press.

Håkansson, N., B. Johansson and O.Vigsø (2014), Politik i det offentliga rummet. Svenska valaffischer 1911-2010, Stockholm: Carlssons.

Johansen, A. (2002), Talerens troverdighet: Tekniske og kulturelle betingelser for politisk retorikk, Oslo: Universitetsforlaget.

Johansen, A. and J. E. Kjeldsen (2005), Virksomme ord. Politiske taler 1814-2005, Oslo: Universitetsforlaget.

Kantorowitz, E. H. (1957), The King's Two Bodies: A Study in Mediaeval Political Theology, Princeton: Princeton University Press.

Kjeldsen, J. E. (2000), 'Visuel politisk epideiktik'. Rhetorica Scandinavica, 14, pp. 18-31.

Kjeldsen. J. E. (2004), Retorikk $i$ vår tid, Oslo: Spartacus.

Kjeldsen, J. E. (2008), 'Visualizing egalitarianism - political print ads in Denmark', in J. Strömbäck, T. Aalberg and M. Ørsten (eds.), Political Communication in the Nordic Countries, Göteborg: Nordicom, pp. 139-160.

Kress, G. and T. van Leeuwen (2010), Reading Images. The Grammar of Visual Design, New York: Routledge.

Krogstad, A. (1999), Image i politikken. Oslo: Pax.

Krogstad, A. and Aa. Storvik (2010), 'Reconsidering Politics as a Man's World: Images of Male Political Leaders in France and Norway', Historical Reflections, 3, pp. 19-38.

Krogstad, A. og Aa. Storvik (2012), 'Picturing politics: Female Political Leaders in France and Norway'. Historical Reflections, 3, pp. 129-152. 
Krogstad, A. (2013), 'Avatarpolitikk som visuell retorikk. Profilbilder på Facebook’, Tidsskrift for samfunnsforskning, 2, pp. 153-185.

Krogstad, A. (2014), 'Kunsten å gjøre ingenting, men være alt'. Rhetorica Scandinavica, 66/67, pp. $35-56$.

Krogstad, A. (2015). 'Visuell politisk retorikk'. In: Ø. Ihlen; E. Skogerbø and S. Allern (eds.), Makt, medier og politikk: Norsk politisk kommunikasjon. Pp. 244-256. Oslo: Universitetsforlaget.

Machiavelli, N. (1958), The Prince, (trans. W. K. Marriot), London: J. M. Dent.

McKeon, R. (1987), Rhetoric: Essays in Invention and Discovery, Woodbridge: Ox Bow Press

Meyrowitz, J. (1986), No Sense of Place. The Impact of Electronic Media on Social Behavior, New York: Oxford University Press.

Mirzoeff, N. (1998), 'What is Visual Culture?', in N. Mirzoeff (ed.), The Visual Culture Reader, London: Routledge, pp. 3-13.

Murphy J. J., R. A. Katula, M. J. Hoppmann, F. I. Hill and D. J. Ochs (2003), A Synoptic History of Classical Rhetoric, London: Lawrence Erlbaum Associates.

Müller, M. G. (2007), 'What Is Visual Communication? Past and Future of an Emerging Field of Communication Research', Studies in Communication Sciences, 7: 2, pp. 7-34.

Norris, P. (2000), A Virtuous Circle. Political Communication in Postindustrial Societies, Cambridge: Cambridge University Press.

Olson, L. C. (2007),'Intellectual and Conceptual Resources for Visual Rhetorics: A Re-Examination of Scholarship Since 1950', The Review of Communication, 7: 1, pp. 1-20.

Oxaal, A. (2001), Drakt og nasjonal identitet 1760-1917, Oslo: Unipub forlag.

Perelman, C. and L. Olbrects-Tyteca (1971), The New Rhetoric. A Treatise on Argumentation, London: University of Notre Dame Press.

Perlmutter, D. (1998), Photojournalism and foreign policy: Icons of outrage in international crises, Westport: Praeger.

Perlmutter, D. D. and G. Golan (2005), 'Counter-imaging: myth-making and Americanization in Israeli Labor Party campaign ads, 2003', Visual Communication, 4, pp. 304-332.

Pettersen, K. (2004), Dress med press, Institutt for kulturstudier, Universitetet i Oslo.

Prior, M. (2013), 'Visual Political Knowledge: A Different Road to Competence?' The Journal of Politics, 0: 0, XXX, pp. 1-17.

Rasmussen, T. (2003), 'Media of the Self. Reflections on the personal web page', Unpublished manuscript. Institutt for medier og kommunikasjon, Universitetet i Oslo.

Rogers, E. M. (1986), Communication Technologies. The New Media in Society, New York: The Free Press. 
Roosevelt, T. (1888), Ranch Life and the Hunting Trail, Harvard College Library Theodore Roosevelt Collection. New York: The Century Co.

Schill, D. (2012). 'The Visual Image and the Political Image: A Review of Visual Communication Research in the Field of Political Communication', The Review of Communication, 12: 2, pp. 118-142.

Shirky, C. (2008), 'The Political Power of Social Media', Foreign Affairs.

http://www.cc.gatech.edu/ beki/cs4001/Shirky.pdf. Accessed 18 November 2016.

Slater, D. (1998), 'Trading sexpics on IRC: embodiment and authenticity on the internet', Body and Society, 4 (4): 91-117.

Sulkin, T., and N. Swigger (2008), 'Is there truth in advertising? Campaign ad images as signals about legislative behavior', The Journal of Politics, 70, 232-244.

http://dx.doi.org/10.1017/S0022381607080164

Thompson, J. B. (2005), Theory, Culture and Society, 22: 6, pp. 31-51. doi: $10.1177 / 0263276405059413$

Vigsø, O. (2004a), Valretorik i text och bild. En studie i 2002 års svenska valaffischer, Uppsala universitet: Skrifter utgivna av Institutionen för nordiska språk, 66.

Vigsø, O. (2004b), 'Politisk marketing - en kort introduktion', Handelshøjskolen i Århus: Center for Virksomhedskommunikation, Working paper no. 5.

Vigsø, O. (2011), 'Valgplakaterne ved folketingsvalget 2011'.

http://www.kommunikationsforum.dk/artikler/valgplakaterne-ved-folketingsvalget-2011. Accessed 21 November 2016.

Villadsen, L. S. and J. B. Hansen (eds.) (2005), Temaintro: Epideiktisk retorik, Skive: Rhetor Forlag.

Walzer, M. (1967), 'On the role of symbolism in political thought, Political Science Quarterly, 82, pp. 191-205.

Weber, M. (1968), On Charisma and Institution Building. Chicago: The University of Chicago Press.

\footnotetext{
${ }^{1}$ The Museums of Florence. http://www.museumsinflorence.com/uffizi/uffizis/uffizin.html. Accessed 15 November 2016.

${ }^{2}$ Harvard College Library Theodore Roosevelt Collection. https://www.nps.gov/thro/learn/historyculture/roosevelt-pursues-boat-thieves.htm. Accessed 15 November 2016.

${ }^{3}$ Diderich Hegerman Lindencrone, Eidsvollsmann. https://www.geni.com/people/Diderich-HegermanLindencrone-Eidsvollsmann/6000000026771374199. Accessed 15 November 2016.
} 
${ }^{4}$ Photographer: Adrian Øhrn Johansen, Dagbladet Magasinet, 13 July 2013.

http://scorpidus.blogspot.no/2013/09/hjemme-hos-var-nye-statsminister.html. Accessed 15 November 2016.

${ }^{5}$ Dagbladet Magasinet, 25 October 2014.

${ }^{6}$ Barack Obama's Facebook.

https://www.facebook.com/barackobama/photos/a.428653951748.228645.6815841748/24664226748/?type=1an dtheater. Accessed 15 November 2016.

${ }^{7}$ Teresa May's Facebook. https://www.facebook.com/TheresaMayOfficial/ Accessed 3 April 2017.

${ }^{8}$ Che Guevara, Wikipedia. https://en.wikipedia.org/wiki/Che_Guevara Accessed 15 November 2016. 